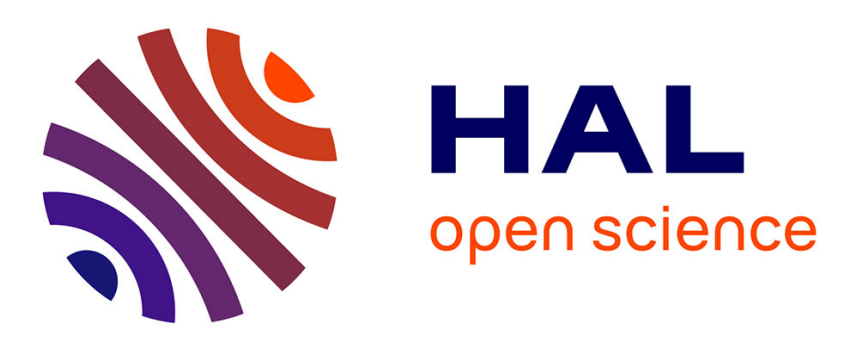

\title{
CoMo/Al2O3 and CoMo/TiO2Al2O3 catalysts in hydrodesulfurization: relationship between the promoting effect of cobalt and the nature of the support
}

M. Vrinat, D. Letourneur, R. Bacaud, V. Harle, B. Jouguet, Christophe Leclercq

\section{To cite this version:}

M. Vrinat, D. Letourneur, R. Bacaud, V. Harle, B. Jouguet, et al.. CoMo/Al2O3 and $\mathrm{CoMo} / \mathrm{TiO} 2 \mathrm{Al} 2 \mathrm{O} 3$ catalysts in hydrodesulfurization: relationship between the promoting effect of cobalt and the nature of the support. Studies in Surface Science and Catalysis, 1999, 127, pp.153-160. 10.1016/S0167-2991(99)80404-2 . hal-00009867

\section{HAL Id: hal-00009867 https://hal.science/hal-00009867}

Submitted on 9 Jul 2021

HAL is a multi-disciplinary open access archive for the deposit and dissemination of scientific research documents, whether they are published or not. The documents may come from teaching and research institutions in France or abroad, or from public or private research centers.
L'archive ouverte pluridisciplinaire HAL, est destinée au dépôt et à la diffusion de documents scientifiques de niveau recherche, publiés ou non, émanant des établissements d'enseignement et de recherche français ou étrangers, des laboratoires publics ou privés.

\section{(c)(1)}

Distributed under a Creative Commons Attribution| 4.0 International License 
$\mathrm{CoMo} / \mathrm{Al}_{2} \mathrm{O}_{3}$ and $\mathrm{CoMo} / \mathrm{TiO}_{2}-\mathrm{Al}_{2} \mathrm{O}_{3}$ catalysts in hydrodesulfurization : relationship between the promoting effect of cobalt and the nature of the support.

\author{
M.Vrinat*, D. Letourneur, R. Bacaud, V. Harlé, B. Jouguet and C. Leclercq
}

Institut de Recherches sur la Catalyse, 2 Av. A. Einstein, 69626, Villeurbanne Cedex,.Fr.

\begin{abstract}
Molybdenum and cobalt-molybdenum catalysts have been prepared over $\mathrm{Al}_{2} \mathrm{O}_{3}$ and a $\mathrm{TiO}_{2}-\mathrm{Al}_{2} \mathrm{O}_{3}$ mixed oxide in order to get more insight on the relation between the nature of the support and the promoting effect of cobalt. These catalysts were characterized by UV-visible diffuse reflectance spectroscopy (DRS), analyzed by energy dispersive spectroscopy (EDS) and evaluated in dibenzothiophene hydrodesulfurization. For the unpromoted catalysts, the $\mathrm{Mo} / \mathrm{TiO}_{2}-\mathrm{Al}_{2} \mathrm{O}_{3}$ sample presented a very high activity as compared to the $\mathrm{Mo} / \mathrm{Al}_{2} \mathrm{O}_{3}$ catalyst. However, over the titania based support a limited activity enhancement by Co promotion was observed. Such a drawback of the $\mathrm{TiO}_{2}-\mathrm{Al}_{2} \mathrm{O}_{3}$ support was correlated to a large amount of cobalt involved in the formation of $\mathrm{CoMoO}_{4}$; moreover, variations observed in the stability of the sulfide phase support these explanations.
\end{abstract}

\title{
1. INTRODUCTION
}

Sulfided CoMo catalysts are used for a long time for hydrotreating processes and these catalysts have generally been prepared over alumina. However, recent environmental specifications regarding the diminution of sulfur and aromatics in transportation fuels have spurred active development of investigation to improve activity and selectivity of such industrial catalysts. As reported in reviews, severals studies suggested that changing the support could improve catalyst activity $[1,2]$.

In this way, a lot of work has been done on $\mathrm{TiO}_{2}$ since it has been shown that molybdenum disulfide supported over such oxide present an intrinsic activity three up to four times higher than over alumina [3,6]. Such interest in the use of $\mathrm{TiO}_{2}$ has been also demonstrated using mixed oxide supports with a 
rich $\mathrm{TiO}_{2}$ content [7-9]. In the case of $\mathrm{MoS}_{2}$ supported over $\mathrm{TiO}_{2}-\mathrm{Al}_{2} \mathrm{O}_{3} 5 \%$, a support with the composition $\mathrm{TiO}_{2}(95 \%) \mathrm{Al}_{2} \mathrm{O}_{3}(5 \%)$, the very high activity as compared to $\mathrm{MoS}_{2}$ supported over $\mathrm{Al}_{2} \mathrm{O}_{3}$ could not be correlated simply with variations in the morphology (length and stacking) of the $\mathrm{MoS}_{2}$ crystallites. Large variations in the reducibility of the supported sulfide were observed, the reducibility of the $\mathrm{MoS}_{2}$ phase being higher when supported over the mixed oxide [8].

Although such oxides appeared promising when used as supports of $\mathrm{MoS}_{2}$, the promoting effect induced by cobalt or nickel is generally lower than that observed over $\mathrm{Al}_{2} \mathrm{O}_{3}$, which fact is still to be understood.

The present contribution deals with the comprehension of the level of this synergetic effect by comparison of Mo and CoMo catalysts prepared over a commercial $\mathrm{Al}_{2} \mathrm{O}_{3}$ and over a $\mathrm{TiO}_{2}-\mathrm{Al}_{2} \mathrm{O}_{3} 5 \%$ mixed oxide prepared by coprecipitation of aluminium and titanium isopropoxydes.

These catalysts were characterized by UV-visible spectroscopy, analyzed by energy dispersive spectroscopy and evaluated in the hydrodesulfurization of dibenzothiophene (DBT).

\section{EXPERIMENTAL}

\subsection{Supports and catalysts preparation}

Preparation of the $\mathrm{TiO}_{2}-\mathrm{Al}_{2} \mathrm{O}_{3}$ support with the molar ratio $\mathrm{Al}_{2} \mathrm{O}_{3} /\left(\mathrm{TiO}_{2}+\mathrm{Al}_{2} \mathrm{O}_{3}\right)=0.05$ has been described in detail previously [9]. Briefly, the method involved the coprecipitation of aluminium and titanium isopropoxydes dissolved in n-propanol by adding acidified water in a large excess. The precipitate was left under slow agitation for $24 \mathrm{~h}$, filtered, washed with demineralized water, dried at $383 \mathrm{~K}$ during $24 \mathrm{~h}$ and then calcined for $4 \mathrm{~h}$ at 823 $\mathrm{K}$. The resulting solid was named $\mathrm{TiO}_{2}-\mathrm{Al}_{2} \mathrm{O}_{3} 5 \%$ and presented a surface area of $160 \mathrm{~m}^{2} / \mathrm{g}$ as determined by nitrogen physisorption using an automated BET apparatus.

Molybdenum was deposited on the carrier by the pore volume method using an aqueous solution of ammonium heptamolybdate of appropriate concentration in order to obtain a solid with 2.8 atoms of molybdenum per square nanometer of support. The impregnated sample was then dried at $393 \mathrm{~K}$ and later calcined at $673 \mathrm{~K}$ for $4 \mathrm{~h}$ (heating rate $2 \mathrm{~K} / \mathrm{min}$ ). In the case of CoMo catalyst cobalt was introduced by coimpregnation using cobalt nitrate, and the molar promoter to molybdenum ratio $r=\mathrm{Co} /[\mathrm{Co}+\mathrm{Mo}]$ was equal to 0.3 .

The $\mathrm{Mo} / \mathrm{Al}_{2} \mathrm{O}_{3}$ catalyst was prepared according to the same procedure using an industrial $\gamma \mathrm{Al}_{2} \mathrm{O}_{3}$ support (surface area $232 \mathrm{~m}^{2} / \mathrm{g}$ ) and the $\mathrm{CoMo} / \mathrm{Al}_{2} \mathrm{O}_{3}$ catalyst was an industrial sample $\left(\mathrm{MoO}_{3}=14 \mathrm{wt} \%\right.$, $\left.\mathrm{CoO} 3 \mathrm{wt} \%\right)$ having the same $\mathrm{Al}_{2} \mathrm{O}_{3}$ support.

\subsection{Catalysts characterization}

Diffuse reflectance spectra (UV-vis DRS) of the catalysts in their oxidic form were obtained in Perkin-Elmer Lambda 9 spectrophotometer using $\mathrm{BaSO}_{4}$ as a reference. 
EDS analyses were performed on a JEOL 2010 FEG electron microscope equipped with a Link Isis microanalysis system. The $\mathrm{H}_{2}-\mathrm{H}_{2} \mathrm{~S}$ sulfided catalyst was dispersed in an ethanol solution and a droplet of the suspension was deposited over a holey carbon film supported on a copper grid. The $\mathrm{K}$ lines of $\mathrm{S}$, $\mathrm{Co}, \mathrm{O}, \mathrm{Al}$ and the $\mathrm{L}$ lines of Mo were selected for quantitative analyses.

\subsection{Catalytic activities}

The HDS of dibenzothiophene was carried out in a continuous flow high pressure microreactor working under a total pressure of $30 \times 10^{5} \mathrm{~Pa}$, with a partial pressure of DBT of $4.80 \times 10^{2} \mathrm{~Pa}$ and $\mathrm{H}_{2} \mathrm{~S}$ added to the feed $\left(252 \times 10^{2} \mathrm{~Pa}\right)$. Experiments were performed between 533 and $588 \mathrm{~K}$.

The HDS activity was expressed by the pseudo first order rate constant calculated after $16 \mathrm{~h}$ time on stream at the pseudo stationary state, by the following equation :

$\mathrm{k}=-\frac{\mathrm{F}_{0}}{\mathrm{~m} \times \mathrm{C}_{0}} \times \ln (1-\mathrm{x})$,

where $\mathrm{k}$ is the rate constant of the reaction $\left(\mathrm{l}^{-1} \mathrm{~g}^{-1} \cdot \mathrm{s}^{-1}\right), \mathrm{F}_{0}$ the molar flow rate of DBT $(\mathrm{mol} / \mathrm{s})$ at the inlet, $\mathrm{x}$ the conversion of reactant, $\mathrm{m}$ the weight of catalyst $(\mathrm{g})$ and $\mathrm{C}$. the concentration of DBT (mol/l).

Prior to catalytic tests the samples were sulfided ex situ under $\mathrm{H}_{2}-\mathrm{H}_{2} \mathrm{~S}(10 \%)$ mixture for $4 \mathrm{~h}$ at $673 \mathrm{~K}$.

\section{RESULTS AND DISCUSSION}

\subsection{Activities :}

Results given in Figure 1 indicate that in the Mo series, the $\mathrm{TiO}_{2}$ rich support leads to a catalyst with a high activity as compared to the $\mathrm{Mo} / \mathrm{Al}_{2} \mathrm{O}_{3}$. For the CoMo samples, we observed a dramatic decrease of the promoting effect of Co when the $\mathrm{TiO}_{2}-\mathrm{Al}_{2} \mathrm{O}_{3} 5 \%$ support is used.

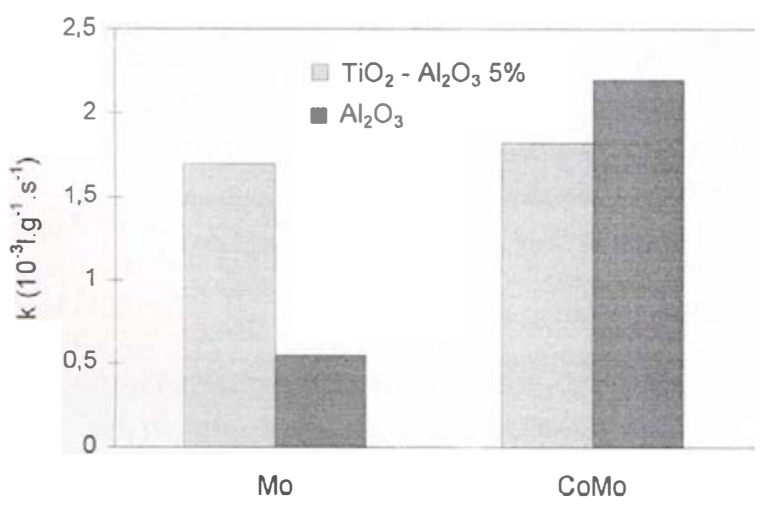

Figure.1. HDS activities compared at $573 \mathrm{~K}$. 
These results confirm previous ones obtained for NiMo catalysts prepared over the same supports and evaluated in aromatic ring hydrogenation (8). Such a low synergetic effect could be explained by a difficult formation of the CoMoS phase during the sulfidation. To answer that question the catalysts have been characterized by UV diffuse reflectance spectroscopy and EDS analysis.

\subsection{Diffuse reflectance spectroscopy :}

The DRS spectra of catalysts in their oxidic state, supported on $\mathrm{TiO}_{2}$ $\mathrm{Al}_{2} \mathrm{O}_{3} 5 \%$ and $\mathrm{Al}_{2} \mathrm{O}_{3}$, are presented in Figure 2. The intense adsorption band at about 240-340 nm, recorded for all samples, could be in first analysis attributed to the ligand-metal charge transfer $\mathrm{O}^{2-} \rightarrow \mathrm{Mo}^{6+}[10,11]$. For the aluminasupported sample, this band would correspond to tetrahedral (250-280 nm) and octahedral (290-330 nm) forms of $\mathrm{Mo}(\mathrm{IV})$. However, in the $\mathrm{TiO}_{2}-\mathrm{Al}_{2} \mathrm{O}_{3}$ supported catalyst, the adsorption at $365 \mathrm{~nm}$ is due to the absorption edge of the $\mathrm{O}^{2-} \rightarrow \mathrm{Ti}^{4+}$ charge transfer band [9], and it is not possible to clearly determine the changes occurring in the molybdenum species, which appear in the 250-330 nm wavelengths range.

For the $\mathrm{CoMo} / \mathrm{Al}_{2} \mathrm{O}_{3}$ catalyst a broad triple band in the $500-700 \mathrm{~nm}$ region is observed. This band could be attributed to ligand field transition of tetrahedral $\mathrm{Co}$ (II) $[12,13]$. In this catalyst this band has been assigned to tetrahedral Co(II) in $\mathrm{CoAl}_{2} \mathrm{O}_{4}$. For the $\mathrm{TiO}_{2}-\mathrm{Al}_{2} \mathrm{O}_{3} 5 \%$ support, the probability to incorporate cobalt into the $\mathrm{Al}_{2} \mathrm{O}_{3}$ to form $\mathrm{CoAl}_{2} \mathrm{O}_{4}$ is strongly reduced due to the low content of this oxide. This could explain why this band is very weak for the titania based support.

In the region $1100-1800 \mathrm{~nm}$, the bands appearing correspond to both octahedral $\mathrm{Co}$ (III) and tetrahedral $\mathrm{Co}$ (II) in oxygen surrounding. For the $\mathrm{CoMo} / \mathrm{Al}_{2} \mathrm{O}_{3}$ catalyst, this octahedral $\mathrm{Co}$ (III) could not be attributed to the presence of oxide compounds like $\mathrm{CoO}, \mathrm{Co}_{3} \mathrm{O}_{4}$ or $\mathrm{CoMoO}_{4}$ [14 - 17]. This point is confirmed by the blue colour of the catalyst. This octahedral $\mathrm{Co}$ (III) would be located near the surface in strong interaction with the molybdates. That interaction is not well defined and Topsøe and Topsøe [15] proposed that the octahedral $\mathrm{Co}$ (III) would be present as $\mathrm{CoO}_{6}$ octahedra associated with the octahedrically coordinated Mo atoms located in one dimensional chains on the alumina surface.

The spectrum of $\mathrm{CoMo} / \mathrm{TiO}_{2}-\mathrm{Al}_{2} \mathrm{O}_{3} 5 \%$ is very different from the one of $\mathrm{CoMo} / \mathrm{Al}_{2} \mathrm{O}_{3}$. A very weak band is observed between 1100 and $1800 \mathrm{~nm}$ and only a little shoulder appears in the region 400-700 $\mathrm{nm}$.

It has been proposed that the low promoting effect of cobalt on $\mathrm{CoMo} / \mathrm{TiO}_{2}$ could be explained by a migration of cobalt in the titania lattice, to form an inactive surface phase, probably anamorphous titanate [3]. To check that possibility a $\mathrm{CoTiO}_{3}$ titanate was prepared as a reference. The spectrum of $\mathrm{CoTiO}_{3}$ is given on Figure 2 and, comparison with that of $\mathrm{CoMo} / \mathrm{TiO}_{2}-\mathrm{Al}_{2} \mathrm{O}_{3} 5 \%$ clearly indicates that cobalt atoms do not migrate in the titania structure.

A Co/ $\mathrm{TiO}_{2}-\mathrm{Al}_{2} \mathrm{O}_{3} 5 \%$ sample with the same amount of cobalt than the $\mathrm{CoMo} / \mathrm{TiO}_{2}-\mathrm{Al}_{2} \mathrm{O}_{3} 5 \%$ was also prepared and its spectrum given in Figure 2 appears very different. In the region $1100-1800 \mathrm{~nm}$, bands prove the presence of tetrahedral and octahedral cobalt confirmed by the large band near $700 \mathrm{~nm}$ and the shoulder near $400 \mathrm{~nm}$ [7]. 


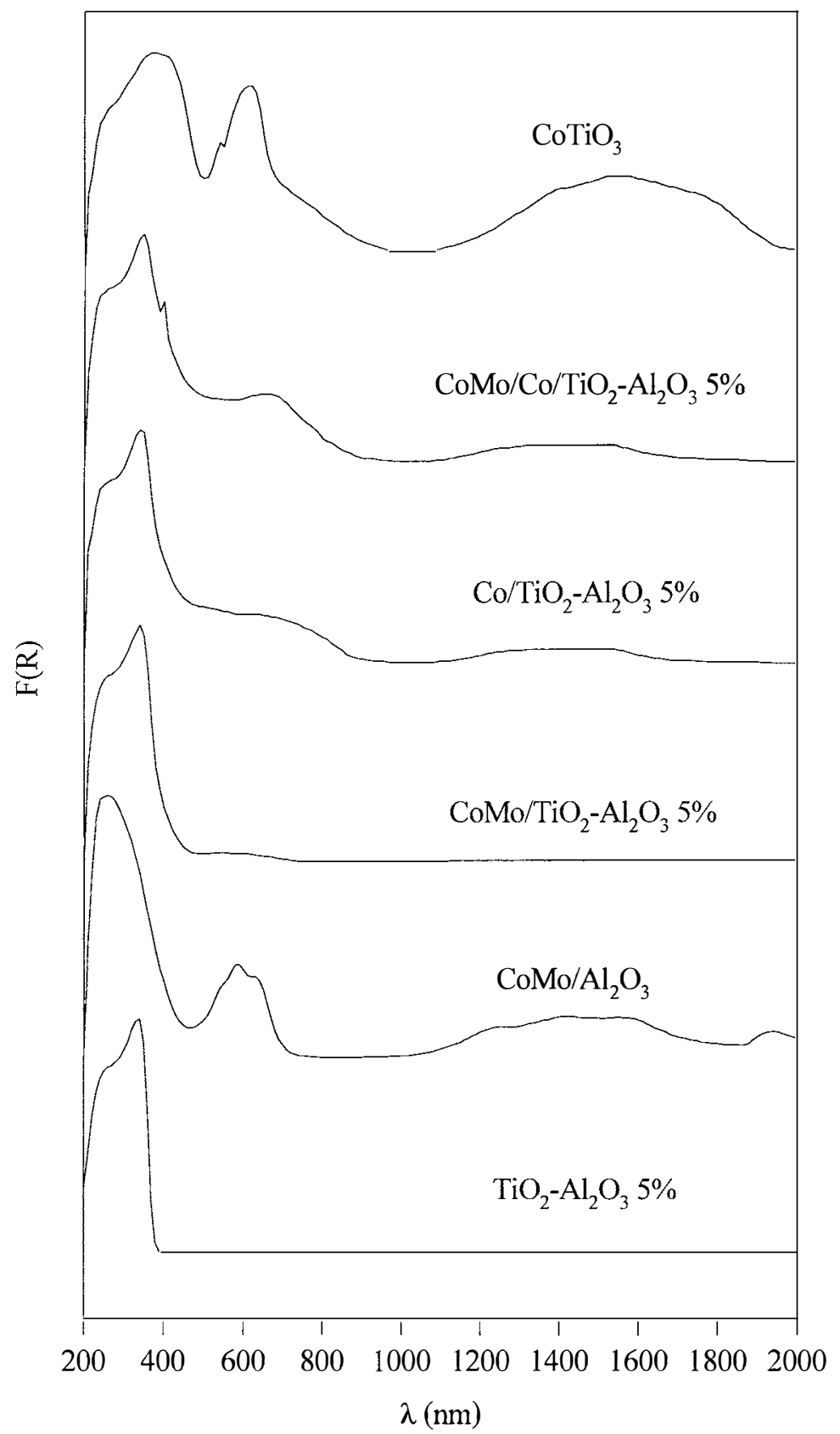

Figure 2. DRS spectra of various catalysts supported on $\mathrm{Al}_{2} \mathrm{O}_{3}$ or $\mathrm{TiO}_{2}-\mathrm{Al}_{2} \mathrm{O}_{3} 5 \%$

This spectrum confirms that cobalt is not incorporated in the titania lattice but that cobalt oxide $\mathrm{Co}_{3} \mathrm{O}_{4}$ is formed. This point is proved by the black colour of this catalyst. When $\mathrm{Co}$ and $\mathrm{Mo}$ are coimpregnated on $\mathrm{Co} / \mathrm{TiO}_{2}-\mathrm{Al}_{2} \mathrm{O}_{3} 5 \%$ only small 
changes in the 400-800 $\mathrm{nm}$ region are observed. The same compound as in $\mathrm{CoMo} / \mathrm{TiO}_{2}-\mathrm{Al}_{2} \mathrm{O}_{3} 5 \%$ is formed. It could be $\mathrm{CoMoO}_{4}$ species in which cobalt has an octahedral structure (low intensity). This compound is known to be difficult to sulfide and to give low activity catalysts [16, 18-19]. This result could explained the low promoting effect for the catalysts supported on $\mathrm{TiO}_{2}-\mathrm{Al}_{2} \mathrm{O}_{3} 5 \%$ by a difficult formation of the $\mathrm{CoMoS}$ phase due to the presence of $\mathrm{CoMoO}_{4}$ in the oxidic precursor. This oxide is easily detected by its light green colour.

\subsection{EDS analysis of sulfided catalysts.}

Our DRS experiments have clearly demonstrated that in calcined CoMo precursors the cobalt atoms located at the surface of the support change with the nature of this oxide. Therefore, variations in the nature of the actives species of the sulfided catalysts are expected. To check that point our samples have been analyzed by EDS. The use of probe size of $2 \mathrm{~nm}$ allow to focus the beam over the $\mathrm{MoS}_{2}$ slabs.

Results given in Figure 3 indicate the $\mathrm{Co} /(\mathrm{Co}+\mathrm{Mo})$ ratios obtained for numerous analyses over the two samples. It is clear that the cobalt is not so homogeneously dispersed over the $\mathrm{TiO}_{2}-\mathrm{Al}_{2} \mathrm{O}_{3} 5 \%$ support than over the alumina, suggesting that on the former support the formation of the CoMo surface phase precursor of the active CoMoS phase is more difficult than over alumina.
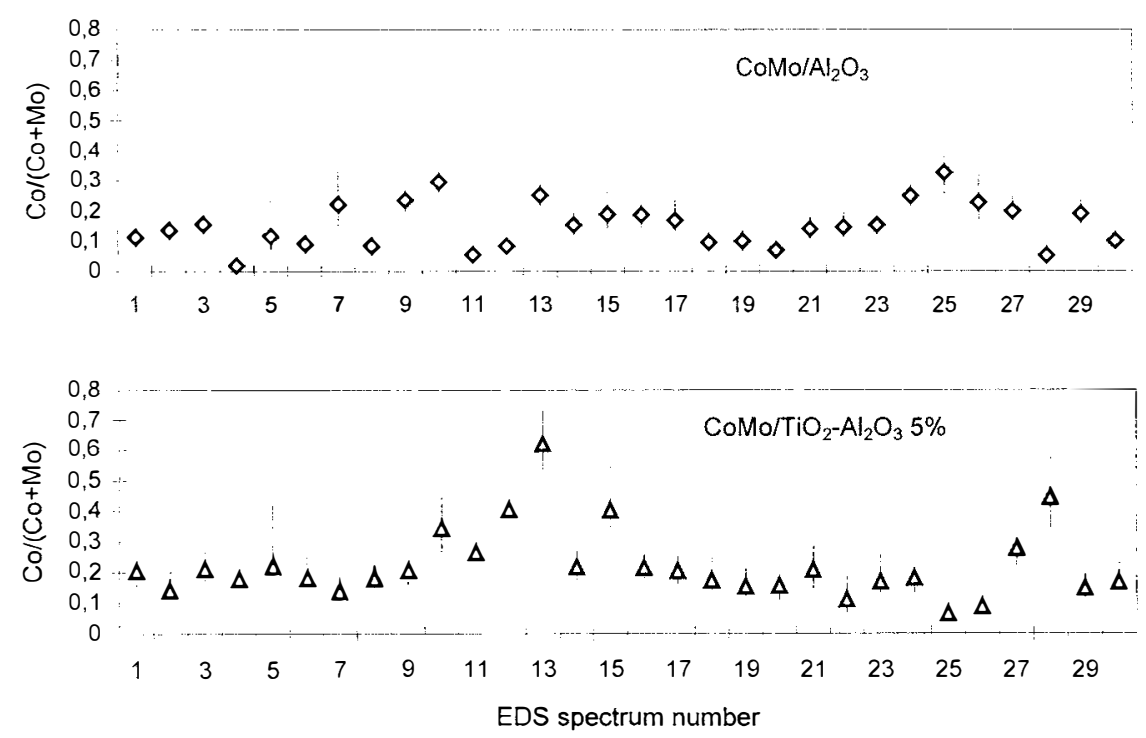

Figure.3. EDS analyses of CoMo sulfided catalysts.

Moreover, it was noticed that over $\mathrm{Al}_{2} \mathrm{O}_{3}$ the $\mathrm{S} /(\mathrm{Co}+\mathrm{Mo})$ atomic ratio decreases after the first analysis upon beam exposure under the small probe size used in these studies. On the contrary, over $\mathrm{TiO}_{2}-\mathrm{Al}_{2} \mathrm{O}_{3} 5 \%$ the phenomenon was considerably less pronounced. That fact, which has never been previously 
reported, could be related to the energy required to form sulfur vacancies which are believed to be the actives sites for many hydrotreating catalysts.

Indeed, several works have been done to try to correlate the HDS activity of sulfides with the metal-sulfur bond energy [20,21]. For promoted catalysts, Byskov et al [22] have recently reported that the presence of cobalt (or nickel) atoms at the edge of $\mathrm{MoS}_{2}$ leads to a significant lowering of the metal sulfur binding energy, and therefore to an increase in the concentration of the active sites for the reaction (promoting effect).

Our DRS results and the EDS analysis appear therefore in good agreement since the lower stability of the sulfur phase observed over $\mathrm{Al}_{2} \mathrm{O}_{3}$ (leading to more uncoordinated molybdenum active sites) is associated with a high dispersion of cobalt in close contact with molybdenum in the oxidic state.

\section{CONCLUSION}

The aim of the present work was to understand the effect of the nature of the support of CoMo hydrotreating catalysts over the level of the promotion induced by cobalt. From the UV-vis data presented above, it is demonstrated than in the case of the $\mathrm{CoMo} / \mathrm{TiO}_{2}-\mathrm{Al}_{2} \mathrm{O}_{3} 5 \%$ catalyst cobalt is not lost into the titania matrix, but mainly involved in the formation of $\mathrm{CoMoO}_{4}$ (hardly sulfided compound). The formation of a CoMo interaction in the oxidic state, assumed to be the precursor of the active CoMoS phase is therefore reduced, in agreement with the lower synergetic effect observed. Moreover, during EDS analysis of the sulfided samples a lower stability of the $\mathrm{CoMo} / \mathrm{Al}_{2} \mathrm{O}_{3}$ was noted. This fact is in line with recent proposals on the effect of cobalt on the lowering of the metalsulfur bond energy, leading therefore to an increase in the concentration of active sites.

\section{Acknowledgements}

The present work was carried within the framework of the program " HDS of Gasoils » supported by ELF, IFP, TOTAL and CNRS-ECODEV.

\section{REFERENCES}

1- M. Breysse, J.L.Portefaix and M. Vrinat, Catal. Today, 10(1991)489.

2- F. Luck, Bull.Soc.Chim.Belg., 100(1991)781.

3- Y.S. Ng and E. Gulari, J.Catal., 95(1985)33.

4- H. Shimada, T.Sato, Y. Yoshimura, J. Haraishi, A. and Nishijima, J. Catal. ,110(1988)275.

5- J. Ramirez, S.Fuentes, G.Diaz, M.Breysse, M.Lacroix and M. Vrinat, Appl.Catal.,52(1989)211.

6- C. Pratt, J.V. Sanders, V. Cristov, J. catal., 124(1990)416.

7- E. Olguin, M. Vrinat, L. Cedeno, J. Ramirez, M. Borque and A Lopez-Agudo, Appl. Catal., 165(1997)1. 
8- V. Harlé, M. Breysse, J. Ramirez and M. Vrinat, Actas XIV Simposio Iberoamericano de Catalisis, Sociedad Chilena de Quimica edit., Vol. 3, 1994, p.1357.

9- J. Ramirez, L. Ruiz-Ramirez, L. Cedeno, V. Harle, M. Breysse and M. Vrinat, Appl. Catal., A93(1993)163.

10- Y. Moro-Oka, S. Tan and A. Ozaki, J. Catal., 12 (1968) 291.

11- H. Praliaud, J. Less. Common. Metals, 54 (1977) 387.

12- H. Ashley, P.C.H. Mitchell, J. Chem. Soc A, (1968) 2821.

13- P. Gajardo, P. Grange, B. Delmon, J. Catal., 63 (1980) 201.

14- C. Wivel, B.S. Clausen, R. Candia, S. Morup, H. Topsøe, J. Catal., 87 (1984) 497.

15- N. Y. Topsøe and H. Topsøe, J. Catal., 75 (1982) 354.

16-.J. A.R. van Veen, E. Gerkema, A.M. van der Kraan, P.A.J.M. Hendriks, H. Beens, J. Catal., 133 (1992) 112.

17-X. Gao, Q. Xin, Catal. Lett., 18 (1993) 409.

18- C. P. Cheng, G.L. Schrader, J. Catal., 60 (1979) 276.

19- J. Medena, C. Van Stam, V.H.J. de Beer, A.J.A. Konings, D.C. Koningsberger, J. Catal., 53 (1978) 386.

20- P. Raybaud, G. Kresse, J. Hafner, H. Toulhoat, J. Phys., Condens., Matter, 2(1997)11085.

21- J. K. Burdett and J.T. Chung, Surf.Sci., 236(1990)L353.

22- L.N. Byskov, B. Hammer, J.K. Norskov, B.S. Clausen and H. Topsoe, Catal. Letters 47(1997)177. 